\title{
THE CATHOLIC CHURCH AND THE MIGRANT CRISIS IN BOSNIA AND HERZEGOVINA
}

DOI: https://doi.org/10.18509/AGB.2021.05

UDC: 272/273-662:314.151.3-054.73-044.372(497.6)

\author{
Jurica Botić1 ${ }^{1}$ Valter Kotlar ${ }^{2}$ \\ ${ }^{1}$ University of Mostar, Bosnia and Herzegovina \\ ${ }^{2}$ Archdiocese of Zadar, Croatia \\ corresponding author: jurica_botic@yahoo.com
}

submitted: 15.04 .2020

accepted: 26.06 .2020

published: 30.09 .2020

\begin{abstract}
The article deals with the attitude of the Catholic Church and the believers in Bosnia and Herzegovina towards the migrant crisis as a case study. In a theoretical sense, the article comes into the theoretical approaches of human geography, primarily the geography of religion and political geography, but also identity studies. In a methodological sense, using the systematic monitoring and analysis of information from the Internet media, but also the conducted survey questionnaire and targeted interview, the article proved the viability of the hypotheses. According to the first one, the Catholic Church in Bosnia and Herzegovina is more restrained than the official Holy See in taking active action in the case of a migrant crisis. Furthermore, according to the second hypothesis, the reason for this more restrained attitude of the Catholic Church in Bosnia and Herzegovina is that the attitude is necessarily linked to identity issues that are closely related to the religious identity of migrants and refugees.
\end{abstract}

Keywords Catholic Church, Bosnia and Herzegovina, migrant crisis, identity, security

\section{INTRODUCTION}

The recent migrant crisis has attracted the attention of the general and professional public in a way that is rarely seen in the case of other social phenomena, often receiving various interpretations that attach to it an epochal character. In fact, the recent migrant crisis has demonstrated and proved the unwillingness of numerous social and, above all, political factors to successfully cope with the many challenges in the social, economic and security fields, as well as the geopolitical repercussions of the changes that such migration trends potentially bring. Certainly, the attitude towards the migrant crisis is not only a social or political issue, but essentially a moral issue that tempts the already adopted and proclaimed values of what we most commonly call the geopolitical West. No matter how much we try to distinguish Christian heritage from the total social heritage of Western societies, it is undoubted that Christian values in various forms are woven into the core values of what we consider to be Western values. In this regard, the attitude of religious communities to the migrant crisis is an indispensable aspect of the attitude of European societies towards refugees and migrants who are arriving at European borders. This paper therefore deals with the attitude of the Catholic
Church towards the migrant crisis, and in the narrowest sense, the attitude of the Catholic Church in Bosnia and Herzegovina towards the abovementioned phenomenon that has been engulfing this country in recent years.

Studying any aspect of the migrant crisis in Bosnia and Herzegovina as a case study is of particular importance if we bear in mind that this country came out of a bloody war only two and a half decades ago, with many citizens of Bosnia and Herzegovina experiencing exile in other European countries. Thus, in a very short time, Bosnia and Herzegovina has been transformed from a refugee country to a country that becomes a temporary refuge for refugees and migrants from other countries, which is a significant exception to other European countries when it comes to the relations toward refugees and migrants. In addition, when it comes to Bosnia and Herzegovina, it should also be borne in mind that Bosnia and Herzegovina is a country of three constituent peoples whose national identities are inseparable from the religious affiliation of their members, and therefore the attitude of the constituent peoples at the collective level corresponds essentially with the attitude towards religious identity of migrants and refugees 
arriving in the territory of Bosnia and Herzegovina. For the purposes of this paper, the authors have focused solely on the attitude of the BosnianHerzegovinian Catholics towards the migrant crisis as a case study, based on the attitude of the official institutions of the Catholic Church in this country

\section{OBJECTIVE AND RESEARCH METHODOLOGY}

The main objective of this paper is to determine the attitude of the Catholic Church in Bosnia and Herzegovina towards the above-mentioned phenomenon that has been engulfing this country in recent years. Accordingly, the authors constructed two hypotheses. According to the first one, the Catholic Church in Bosnia and Herzegovina is more restrained than the official Holy See in taking active action in the case of a migrant crisis. Furthermore, according to the second hypothesis, the reason for this more restrained attitude of the Catholic Church in Bosnia and Herzegovina is that the attitude is necessarily linked to identity issues that are closely related to the religious identity of migrants and refugees.In the case of the first hypothesis, the methodological framework of the research involves

\section{THEORETICAL ASPECTS OF RESEARCH}

As an integrative discipline concerned with the interactions among diverse phenomena in particular places and across space, geography provides a useful context for examining religion as an integrative element of culture [9]. As a discipline within human geography, the geography of religion deals with the relation between religion and geographical space. Within contemporary, postmodern settings, the articulation of cultural identity has become extremely important, containing a whole range of various identification levels. Thereby, religion is one of the crucial factor in the articulation and reproduction of cultural identity [9]. Therefore, Berger rightly points out that those who neglect religion in their analyses of contemporary events do so at their own expense [2]. According to Huntington's neoconservative discourse, the greatest divisions and dominant sources of conflict in the future will be cultural, while identity is culturally conditioned and cannot be changed. Moreover, Huntington claims that the central axis of international relations is a conflict between "The West and The Rest", with The Rest attempting to challenge the primacy and domination of the West. As a representative of critical geopolitics, Ó Tuathail objects to this view, pointing out that cultural complexity and geographical diversity are reduced to only a few macro categories, in this case civilizations, while the global space has been stripped of its plurality and the World politics of its multiplicity. Furthermore, Ó Tuathail is particularly critical of to the phenomena related to the migrant crisis. Therefore, this paper deals with the theoretical fields of human geography in a broad sense, and in the narrow sense it comes into theoretical approaches in political geography, geography of religion and identity studies.

the systematic monitoring and analysis of information from the Internet media, and the determination of the extent and spatial distribution of aid and support to refugees and migrants by the Catholic Church throughout Bosnia and Herzegovina, and especially in the area of particular dioceses in this country. Certainly, the established results have been properly interpreted cartographically. Furthermore, in the case of the second hypothesis, besides monitoring and analysing information from the media, the authors sought to prove or disprove the hypothesis by the conducted survey questionnaire and targeted interview with Ms. Dijana Muzička, Head of the Caritas Bosnia and Herzegovina Emergency and Migrant Crisis Program, as an expert.

Huntington's attitude about identity as an immutable category and the thesis that multiple identities, especially religious ones, create conflict. Specifically, disputing such a thesis, Ó Tuathail cites the example of wars in the former Yugoslavia in the 1990s, considering that they were caused by the manipulation of elites in the midst of an economic crisis, not by religious and ethnic diversity per se [8]. Unlike Huntington's clash of civilizations, Giddens's understanding of civilization points to the violation of those traditional places by new spaces of flows [5]. Globalization and the information revolution have weakened the links of major religions with the territory from which they originated and weakened their hierarchical structures [6].

Migrations traditionally have religious significance as well. By focusing on the subject of the research, we will keep our focus on Muslim migrations. Of course, this does not mean that similar examples of the spread of religion through migration do not exist in the cases of other religions, but rather, we find such examples in the spread of Christianity in the New World or the return of Jews to the Promised Land. For example, starting with the hijra, that is, the migration of Muhammad and his followers from Mecca to Medina, Muslims have for centuries migrated from Dar al-Harb (the Realm of War) to Dar al-Islam (the Realm of Islam). This obligation applied to those Muslims who were unable to participate in jihad, the effort to expand Dar alIslam [9]. On the other hand, Islam is spreading 
very effectively in areas that were already under the control of Muslim rulers in the early centuries of Islam. The effective spread of Islam should also be viewed in the context of jihad, which "perhaps best illustrates the tendency to essentialize Islam and construct it as a geopolitical other", whereby the understanding of the term is completely different within the Islamic world and the West. While for Muslims it means "to strive or struggle in the way of God" as "a central component of the Islamic faith", the West sees jihad "as holy war - with emphasis upon war" [5]. Understanding jihad also through the dimension of missionary activity, though less in institutional form than in the case of Christian churches, Islam has found a way to expand into areas not traditionally considered Islamic [9].

In some political circles in Europe, there is concern about Islamizing Europe and converting it to Eurabia, although estimates show that the proportion of the Muslim population in Europe by 2050 will not rise above $15 \%$ [6]. According to Moïsi, Europeans' attitude to religion also contributes significantly to this. Moïsi points out that while Islam is a spreading religion on the one hand and mosques are full, Christianity, especially in Europe, is weak and churches are empty [7]. However, secularization theory has mistakenly assumed that modernity necessarily leads to a decline in religion. In fact, religious communities not only survived, but also flourished to the extent that they did not attempt to adapt to the supposed demands of the secularized world. Moreover, research conducted in France, the United Kingdom and Scandinavia shows a strong survival of religion, but with marked alienation from organized churches [2]. Therefore, reaffirming religion is a phenomenon that must be seriously reckoned with, and reasons for empty churches can be sought in the deinstitutionalized religiosity of Europeans.

In this article, we will not discuss the similarities and differences between Christianity and Islam, nor the compatibility of the values of these two religions and those values that we colloquially call Western, and most commonly define them as liberal democracy values. However, it is certainly worth pointing out that the basic idea of secularism, embodied in Jesus' instruction "Render unto Caesar the things that are Caesar's, and unto God the things that are God's", has survived numerous challenges over the centuries and has resulted in the establishment of secular political systems. Thus,

\section{RELATIONS OF THE CATHOLIC CHURCH AND BELIEVERS IN BOSNIA AND HERZEGOVINA TOWARDS MIGRANTS}

Highlighting the traditional interconnection of religion and politics, Jean notes that politics seeks to territorialize religions through concordats, even those of an ecumenical character [6]. However, the interconnection of religion and politics in the so-called western Balkans, and especially in Bosnia and secularism has come to life in Europe not in spite of, but thanks to Christianity, which has resulted in a social framework conducive to the development of pluralistic thought, and ultimately the possibility of the free introduction of Islam into the European social context. Therefore, in line with the previously discussed considerations on secularization, this term should not be interpreted solely in the context of moving away from religiosity, but in defining the relation between church and state.

Developing a thesis on the culture of humiliation that arises from his idea of the geopolitics of emotions, Moïsi points out that Muslims have not gained respect from Christians, but solely tolerance [7]. However, Jesus asks Christians to love their neighbour as themselves. The concept of the neighbour in the New Testament is defined not by theological or ethnic, but by the ethical key, and therefore the neighbour is always the one who needs our help. Since in the Gospel axiology the quality and measure of our love for God are determined by the quality and measure of our love for our neighbour, one cannot love God unless he/she loves his/her neighbour, including the Muslim in his/her need [4]. From this relation to one's neighbour also emerges the attitude of Christianity towards universal human rights. In defence of universal human rights, Pope John Paul II does not set forth Catholic principles, but principles acceptable to any rational person. Therefore, by defending universal human rights, John Paul II defends universal human nature [10]. The example of Pope Francis washing immigrants' feet is much more than, as Ahmed puts it, the example of "convivencia", but rather points to "actions that embody the courage, compassion, and humility of the best of European humanism" [1]. Certainly, European humanism has its deep roots in the Christian ethics of attitudes towards one's neighbour. In addition, the Catholic Church sponsors approximately 172800 educational institutions worldwide (from rural institutions to recognized universities) and runs about 105100 community institutions - hospitals, dispensaries, clinics, homes for the elderly, sick, disabled, orphans, kindergartens and spouses counselling [10]. Finally, the messages of Pope Francis as head of the Catholic Church have always clearly and unequivocally indicated openness to migrants and the obligation of Catholics to provide aid.

Herzegovina, is not territorial, but ethno-national in nature, and such interconnection is often manifested in the mobilization of the clergy for the purpose of propagating the particular interests of a particular people belonging to that particular religious group. 
Researching online articles published in Bosnia and Herzegovina and Croatia that dealt directly or indirectly with relation of the Catholic Church in Bosnia and Herzegovina to migrants in the period January 2019 to February 2020, it was determined that there were only 26 such articles published during these fourteen months. From the above it is quite evident that the official Catholic Church in Bosnia and Herzegovina is quite restrained when it comes to the migrant issue, since news items related to this issue were published twice a month on average. However,
$73 \%$ of the articles convey a positive attitude of the Church or believers towards migrants, with a very determined emphasis on their willingness to help this population. On the other hand, $19 \%$ of articles show a positive attitude towards the migrant population, but with some warnings from Church dignitaries about the security challenges this problem brings, while only $8 \%$ of articles bring negative connotations in the attitude of Church representatives toward migrants, especially pointing to security challenges in Bosnia and Herzegovina.

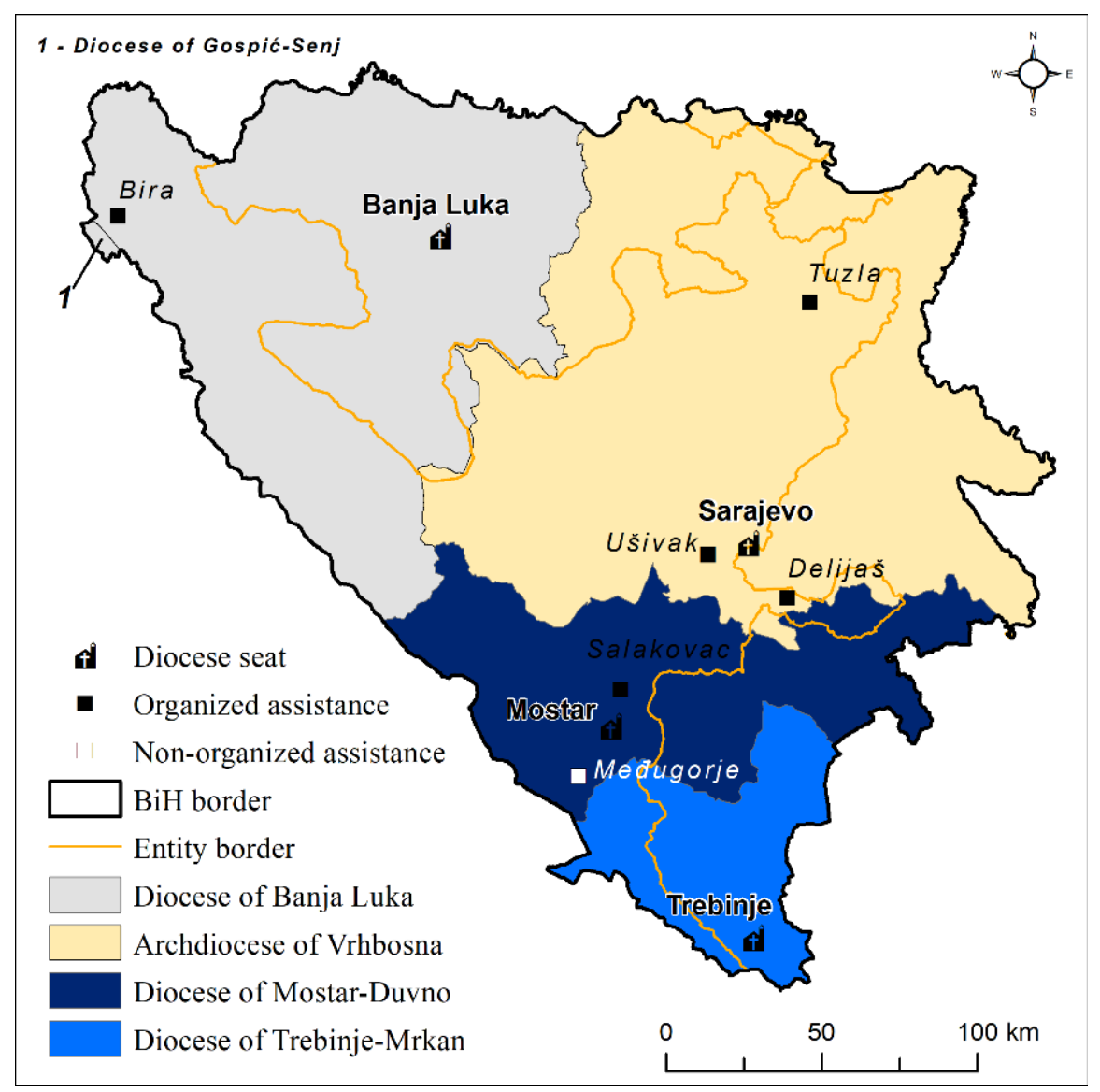

Figure 1. Organized and non-organized aid to migrants

by the Catholic Church in Bosnia and Herzegovina.

However, it is important to note that almost half of the articles analysed (46\%) talk about some form of aid to migrants by the Catholic Church or the faithful, the majority $(88 \%)$ referring to organized aid by Caritas. Spatially speaking, the Church provided aid in an organized manner throughout Bosnia and Herzegovina: on the territory of the Archdiocese of Vrhbosna (Sarajevo) at official reception centres and camps in Delijaš and Ušivak near Sarajevo and temporary accommodation in Tuzla; in the territory of the Diocese of Banjaluka in the temporary camp of Bira near Bihać; and in the territory of the Mostar-Duvno diocese in the official reception centre Salakovac near Mostar, but also in Međugorje in the case of migrants accidentally strayed in the area (Map 1). There are no recorded forms of aid to migrants in the territory of the Trebinje-Mrkan Diocese, but bearing in mind that the bishop of Mostar-Duvno is responsible for this diocese, we can consider the aid of the two dioceses as a whole. Dijana Muzička, Head of the Caritas Bosnia and Herzegovina Emergency and Migrant Crisis Program, confirmed this information in the interview. According to the above, although the organized aid of the Church has been proven, the frequency of aid news appearances proves that the first hypothesis is confirmed, i.e. that the Catholic Church in Bosnia and Herzegovina is more restrained than the official Holy See in taking active action in the case of a migrant crisis.

A survey similar to this research was conducted in 2018 among the student population of all 
constituent peoples in Bosnia and Herzegovina. For the purposes of this research, we will compare results related only to students of Croat ethnicity with the results of this research in the part that addresses the same questions raised. For example, half of them thought that the migrant crisis was affecting the entire society, while a quarter pointed to its impact on peoples' relations. Furthermore, even one fifth students of Croat ethnicity considered Bosnia and Herzegovina unprepared to face the migrant crisis, and only a small number would accept all migrants, while a third thought that Bosnia and Herzegovina should accept migrants, but not all. Almost half of them claimed that Bosnia and Herzegovina should not accept migrants at all, and only one tenth of them would be willing to live in the neighbourhood of migrants, while a quarter of Croat students would be willing to live in the neighbourhood of migrants who passed the security check. However, it should be noted that they rarely spoke about the same religion as a condition for accepting migrants, since they indicated a security check more often as a key criterion for accepting migrants rather than a religion [3]. However, insisting on a security check may also indicate a developed prejudice against the majority religious affiliation of migrants.

For the purpose of this research, a survey questionnaire was conducted on a sample of 208 adult random Croat respondents in Bosnia and Herzegovina. The targeted interview was used as a kind of verification and corrective of the survey results. In the SPSS program, a chi-square test of responses related to respondents' attitudes about migrants was conducted. Due to the small number of respondents in relation to the total population of Croats in Bosnia and Herzegovina, the sample is not considered representative but is certainly considered indicative. The survey included 88 men and 120 women, with no significant difference in their responses. The sample includes $33.7 \%$ of respondents under $30,34.1 \%$ of respondents are 31 to $45,23.1 \%$ of respondents are 46 to 60 , and $9.1 \%$ of respondents are over 60, which deviates from the actual age structure of Croats in Bosnia and Herzegovina. Only $1 \%$ of respondents have neither completed primary school, $2.9 \%$ have completed primary school, $29.8 \%$ have completed secondary school, even $(50 \%)$ have completed undergraduate or graduate study, and $16.3 \%$ have completed postgraduate study. The largest number of respondents $(26.4 \%)$ of respondents has income from $€ 500$ to $€ 750$, and it is indicative that almost one fifth $(19.2 \%)$ have no income. It is worrying that even one third of the respondents $(32.9 \%)$ of those under 30 have no income at all. Of those with income, even $39.4 \%$ of respondents are employed in the public sector and $34.6 \%$ work in the private sector, either as employees $(23.1 \%)$ or as business owners $(11.5 \%)$. Even half of the respondents have a right $(23.1 \%)$ or mostly right $(26.4 \%)$ political orientation, while even $35.1 \%$ of them are not interested in politics, of which even half are under 30 years of age. It is interesting to note that even half $(49.5 \%)$ of the respondents claimed to be religious in line with the teachings of their religion. There are $31.7 \%$ of religious who are not regular at masses, while the number of those who are not religious at all is negligible (1\%).

The overwhelming majority of respondents do not think (39.4\%) or do not think at all $(28.4 \%)$ that Bosnia and Herzegovina was ready for the migrant crisis. However, Ms. Muzička, as a representative of Caritas, believes that Bosnia and Herzegovina had a well-designed operational plan for the migrant crisis, which proved to be insufficient for so many migrants. More than half of the respondents $(54.3 \%)$ think that the migrant crisis will affect the entire society in Bosnia and Herzegovina, and $21.2 \%$ think that it will affect relations among constituent peoples, which is somewhat similar to the results on the student population in an earlier study. Ms. Muzička has a similar opinion. More than two-thirds (69.7\%) of respondents believe that Bosnia and Herzegovina should not accept migrants on its territory, and a quarter (24\%) of them believe that it should, but not all of migrants, while $5.8 \%$ of respondents does not know how to respond question, with only $0.5 \%$ of respondents saying that this country should accept all migrants. Among those who approve the acceptance of migrants to a greater or lesser extent, two-thirds of respondents say that they are bound by their Christian faith (34.9\%) or humanity $(33.3 \%)$. However, it is interesting that only $3.2 \%$ of respondents who do not refuse to accept migrants opt for a rational argument such as the fact that Bosnia and Herzegovina is demographically deprived, while $11.1 \%$ state that other countries have also received refugees from Bosnia and Herzegovina.

When comparing the results by the chi-square test with the levels of readiness to accept migrants, it is found that all respondents who believe that Bosnia and Herzegovina should receive all migrants claim that they are bound by the Christian faith. On the other hand, respondents who believe that this country should accept migrants, but not all, equally point out that it is a matter of humanity $(40 \%)$ and Christian faith (38\%). Such responses undoubtedly point to the importance of Christian identity in shaping attitudes towards migrants. There are smaller differences in the percentages of answers on the reasons for not accepting migrants, with $23.6 \%$ 
of respondents considering that migrants do not culturally fit into the Bosnian-Herzegovinian society, $22.9 \%$ of them consider that migrants represent a security challenge, $22.9 \%$ claim that this the country does not have the financial resources to accept migrants, and $17.2 \%$ believe that Bosnia and Herzegovina is not their target destination. As the cultural aspect is necessarily directed at religious identity, it is undisputed that arguments against migrant acceptance are also linked to identity issues. These results are less favourable than the student survey results described above, as the student population showed a slightly higher willingness to accept migrants.

Almost two-thirds of respondents (62.5\%) are not ready to live in the neighbourhood of migrants. Furthermore, $16.8 \%$ of them are willing to live only in the neighbourhood of those migrants who pass the security check, and $6.3 \%$ of respondents agree to live alongside the migrants of their religion. Conducting chi-square testing of these results in relation to levels of readiness to accept migrants, almost four-fifths (78.6\%) of respondents who believe that Bosnia and Herzegovina should not accept migrants say they are not ready to live in the neighbourhood of migrants, unlike half of those who believe that this country should accept

\section{CONCLUSION}

Based on the conducted research and application of the research methodology, it was found that the research mostly confirmed the hypotheses. In fact, the research did confirm the existence of a significant level of restraint of the Catholic Church in Bosnia and Herzegovina in the relation to official policy of the Holy See when it comes to active response to a migrant crisis in this country. This conclusion relates primarily to the restraint of the High Clergy in Bosnia and Herzegovina in presenting official attitudes and sending strong messages to the general public, especially to Catholic believers in this country and defining their role in the circumstances of the migrant crisis. However, the research has at the same time proved the existence of numerous and various forms of aid provided by the Catholic Church in Bosnia and Herzegovina to refugees and migrants, most notably through the already established and organized operation of Caritas as a key charitable migrants, but not all, who claim to be ready to live alongside migrants who pass the security screening. The reasons for possibly accepting living in a migrant neighbourhood are similar to the reasons given by the student population in the 2018 survey. In contrast to all the above, the representative of Caritas points out the help that the Church provided to migrants and calls on Catholics to help all people in need, including migrants.

The results of the survey of the attitudes of Catholic believers towards migrants indicate that the attitudes were significantly formed on the basis of the respondents' identity determinants. Bringing the results of the survey in correlation with the already observed restrained attitude of the Catholic Church in Bosnia and Herzegovina towards migrants, it can justifiably be argued that the Church's attitude is strongly correlated with the identity strongholds of its followers. Therefore, based on the results obtained, it is found that the survey and targeted interview mostly confirmed the second hypothesis that the reason for the more restrained attitude of the Catholic Church in Bosnia and Herzegovina towards the migrant crisis is that the attitude is necessarily linked to identity issues that are closely related to the religious identity of migrants and refugees.

organization of the Catholic Church operating in all dioceses in this country.Furthermore, the research also confirmed that the reason for the more restrained attitude of the Catholic Church in Bosnia and Herzegovina relative to the official Holy See towards the migrant crisis is that the attitude is necessarily linked to identity issues that are closely related to the religious identity of migrants and refugees. Indeed, the conducted survey mostly proved that the Catholics of Bosnia and Herzegovina significantly correlate their attitude towards migrants and refugees with their religious affiliation. Bosnian-Herzegovinian Catholics often interpret such a relation as a fear of potential threats and security challenges, as well as cultural differences between migrants and the local population, with the situation of a declining number of Catholics in this country being seen as the most vulnerable.

\section{REFERENCES}

[1] Ahmed, A. Journey into Europe: Islam, Immigration, and Identity, Washington D.C.: Brookings Institution Press, 2018.

[2] Berger, P. L. Desekularizacija sveta: opšti pregled, in: Berger, P. L. et al. (Ed.) Desekularizacija sveta: oživljavanje religije i svetska politika, Novi Sad: Mediterran Publishing, pp 11-30, 2008. 
[3] Botić, J. Geopolitical Reflections of Turning the Western Balkan Migrant Route towards Bosnia and Herzegovina, IEMC 2018: International Eurasia Migration Conference, 9-13 October 2018, Turkestan, Kazakhstan: Proceedings Book, Istanbul: İstanbul Medeniyet Üniversitesi, pp 34-59, 2018.

[4] Đurić, M. Rušiti zidove i graditi mostove u duhu, Zagreb: Mešihat Islamske zajednice u Hrvatskoj, 2010.

[5] Flint, C. \& Taylor, P. Political Geography: World-Economy, Nation-State and Locality, London: Routledge, 2011.

[6] Jean, C. Geopolitica del mondo contemporaneo, Bari: Editori Laterza, 2012.

[7] Moïsi, D. Geopolitika emocija: kako kulture straha, poniženja i nade utiču na oblikovanje sveta, Beograd: Clio, 2012.

[8] Ó Tuathail, G. Uvod u treći dio, in: Ó Tuathail, G., Dalby, S. \& Routledge, P. (Ed.) Uvod u geopolitiku, Zagreb: Politička kultura, pp 137-152, 2007.

[9] Stump, R. W. The Geography of Religion: Faith, Place and Space, Lanham: Rowman \& Littlefield Publisher, 2008.

[10] Weigel, G. Desekularizacija sveta: opšti pregled, in: Berger, P. L. et al. (Ed.) Desekularizacija sveta: oživljavanje religije i svetska politika, Novi Sad: Mediterran Publishing, pp 31-49, 2008. 